\title{
PENGARUH RASIO LIKUIDITAS, LEVERAGE, KOMITE AUDIT TERHADAP KINERJA KEUANGAN PADA PERUSAHAAN BARANG KONSUMSI YANG TERDAFTAR DI BURSA EFEK INDONESIA
}

\author{
Penulis: \\ Hantono $^{1}$ \\ Jony $^{2}$ \\ Afiliasi: \\ Universitas Pelita \\ Harapan Medan (UPH) \\ Medan ${ }^{1,2}$ \\ Korespondensi: \\ hantono_78@yahoo.com \\ jonychang.ca@gmail.com \\ Histori Naskah: \\ Submit: 99-00-9999 \\ Accepted: 99-00-9999 \\ Published: 99-00-9999
}

\begin{abstract}
Abstrak:
Penelitian ini bertujuan untuk melihat faktor-faktor yang mempengaruhi likuiditas, leverage, komite audit dengan menggunakan data laporan keuangan dari barang konsumsi yang terdaftar di Bursa Efek Indonesia. Beberapa faktor yang dapat mempengaruhi kinerja keuangan di dalam penelitian ini di antaranya adalah likuiditas, komite audit, leverage. Metode pengambilan sampel yang digunakan adalah purposive sampling dan model analisis data yang digunakan adalah analisis regresi linear berganda dengan jenis data adalah data sekunder. Sampel yang digunakan dalam penelitian adalah 8 perusahaan. Hasil dari penelitian ini menunjukkan bahwa variabel yang berpengaruh signifikan terhadap return on assets adalah likuiditas dan leverage yang diproksikan dengan debt to asset ratio berpengaruh dan signifikan secara parsial, sementara komite audit tidak berpengaruh dan tidak signifikan secara parsial terhadap opini return on assets pada perusahaan consumer goods yang terdaftar di Bursa Efek Indonesia periode 2017 - 2020. Sementara secara simultan seluruh variabel independen berpengaruh terhadap return on assets. Nilai Adjusted $R$ Square pada penelitian ini sebesar 0,535 artinya bahwa kontribusi variabel likuiditas, leverage dan komite audit dalam menjelaskan variable kinerja keuangan yang diproksi dengan return on assets ialah sebesar $53.5 \%$ dan dan sisanya $46,5 \%$ dijelaskan oleh variabel lain diluar variabel yang diuji.
\end{abstract}

Kata kunci: Likuiditas, Leverage, Komite Audit, dan Kinerja Keuangan

\section{Pendahuluan}

Informasi mengenai keadaan keuangan sangat dibutuhkan bagi suatu perusahaan, yang bertujuan untuk dapat digunakan sebagai salah satu alasan pengambilan keputusan ekonomi perusahaan. Kinerja suatu perusahaan merupakan kemampuan yang wajib dicapai pada suatu periode tertentu menjadi output berdasarkan proses kerja. Kinerja perusahaan bisa diukur menggunakan 4 rasio keuangan antara lain yaitu rasio profitabilitas, rasio likuiditas. Rasio profitabilitas adalah rasio yang dipakai buat mengukur kemampuan perusahaan untuk menghasilkan keuntungan berdasarkan pendapatan yang berhubungan dengan penjualan, aset dan ekuitas. Sementara rasio likuiditas menunjukkan bagaiamana perusahaan sanggup memenuhi kewajiban jagka pendek atau utang lancarnya. 


\section{- 1 - Jurnal Audit \& Perpajakan}

Volume : 1 | Nomor 1 | November 2021 | E-ISSN : 2809-1809. | DOI: 10.47709/jap.v1n1.1165

Tujuan laporan keuangan adalah untuk memberikan informasi kepada pihak luar perusahaan mengenai posisi keuangan, kinerja keuangan dan arus kas entitas yang bermanfaat bagi pengguna laporan untuk mengambil keputusan ekonomi sesuai dengan kebutuhan pengguna laporan keuangan (IAI 2015, 1.3). Informasi yang digunakan dalam mengukur kinerja keuangan adalah informasi keuangan, akuntansi manajemen informasi, dan informasi akuntansi keuangan seperti laba sebelum pajak, laba atas investasi dan sebagainya. Laporan keuangan dapat diperoleh dari arsip-arsip perusahaan yang dipublikasikan misalnya dalam annual report dan laporan keuangan tahunan. Annual report berisi informasi-informasi mengenai perusahaan seperti dewan komisaris, dewan direksi, komite audit, sekretaris perusahaan, laporan keuangan dan lain-lain

\section{Studi Literatur}

\section{Likuiditas}

Likuiditas adalah tingkat kemampuan perusahaan di dalam memenuhi kewajiban jangka pendeknya dengan aktiva lancar yang dimiliki(Prabowo \& Sutanto, 2019). Likuiditas menggambarkan kesanggupan perusahaan melakukan pembayaran sebelum habis masa tiba kewajiban jangka pendek atau utang lancar menggunakan aset lancarnya. Semakin tinggi likuiditas perusahaan maka artinya semakin baik kondisi keuangan perusahaan(Nurcahyani \& Situngkir, 2021). Likuiditas adalah berhubungan dengan masalah kemampuan suatu perusahaan untuk memenuhi kewajiban finansialnya yang segera harus dipenuhi jumlah alat-alat pembayaran (alat likuid) yang dimiliki oleh suatu perusahaan pada suatu saat merupakan kekuatan membayar dari perusahaan yang bersangkutan.(Shabrina, 2019). Menurut Hanafi ( 2016 : 75), di dalam (Hantono, 2020), rasio likuiditas mengukur kemampuan likuiditas jangka pendek perusahaan dengan melihat aktiva lancar perusahaan relatif terhadap utang lancarnya (utang dalam hal ini merupakan kewajiban perusahaan). Likuiditas merupakan salah satu kinerja yang sering dijadikan tolak ukur investor dalam menilai perusahaan(Purba \& Candradewi, 2019). Likuiditas menggambarkan kemampuan perusahaan untuk menyelesaikan kewajiban jangka pendeknya(Margaretta et al, 2019). Indikator likuiditas dalam penelitian ini menggunakan current ratio. Menurut(Hantono, 2017), indikator current ratio :

\section{Leverage}

$$
\text { Current Ratio }=\frac{\text { Aktiva Lancar }}{\text { Utang Lancar }}
$$

Menurut Hantono (2017:12), solvabilitas adalah rasio yang digunakan untuk menghitung leverage perusahaan. Menurut Harahap (2016:303), solvabilitas adalah rasio yang menggambarkan kemampuan perusahaan dalam membayar kewajiban jangka panjangnya atau kewajiban-kewajibannya apabila perusahaan dilikuidasi. Rasio solvabilitas yang dalam penelitian ini menggunakan debt to asset ratio, dilakukan dengan tujuan untuk mengukur seberapa besar aset perusahaan yang dibiayai dengan utang. Leverage merupakan suatu hal kemampuan yang dimiliki perusahaan untuk memenuhi kewajiban finansialnya baik itu dalam jangka pendek maupun jangka panjang dan menghubungkan antara utang perusahaan terhadap modal, sehingga perusahaan yang sudah melakukan pinjaman akan mempunyai kewajiban atas beban bunga dan bunga pokok pinjaman(Sofiantin, 2020). Leverage memiliki arti yaitu perusahaan melakukan pembiayaan 
dengan melakukan peminjaman dana dengan kata lain perusahaan ber-utang. Leverage ini sering digunakan oleh investor dan perusahaan untuk memperoleh pengembalian laba asset yang lebih besar. Namun hal ini mungkin dapat malah menjadi kerugian yang lebih besar (Quan \& Ardiansyah, 2020). Leverage merupakan penggunaan hutang oleh perusahaan sebagai sumber pembiayaan untuk melakukan kegiatan perusahaan dimana untuk menggunakannya perusahaan harus membayar biaya tetap(Riswanto, 2021). Sebuah perusahaan yang memiliki leverage yang tinggi, mengindikasikan bahwa perusahaan tersebut cenderung memiliki kemampuan yang rendah dalam memenuhi kewajibannya(Setiawati et al., 2020). Indikator leverage dalam penelitian ini menggunakan debt to asset ratio. Menurut(Hantono, 2017), indikator current ratio :

\section{Komite Audit}

$$
\text { Debt to Assets Ratio }=\frac{\text { Total Debt }}{\text { Total Equity }}
$$

Menurut Ikatan Komite Audit Indonesia (IKAI) dalam Effendi (2009:25), komite audit adalah suatu komite yang bekerja secara professional dan independen yang dibentuk oleh dewan komisaris dan, dengan demikian, tugasnya adalah membantu dan memperkuat fungsi dewan komisaris (atau dewan pengawas) dalam menjalankan fungsi pengawasan (oversight) atas proses pelaporan keuangan, manajemen risiko, pelaksanaan audit dan implementasi dari corporate governance di perusahaan-perusahaan.

Menurut Arens, et.al. (2014:104), komite audit adalah sejumlah anggota dewan direksi perusahaan yang tanggung jawabnya termasuk membantu auditor agar tetap independen dari manajemen.

Menurut Surya dan Ivan (2008:146-147), syarat komite audit terdiri dari sekurangkurangnya 1 (satu) orang komisaris independen dan sekurang-kurangnya 2 (dua) orang anggota lainnya berasal dari luar emitmen atau perusahaan publik.

Dengan demikian, indikator komite audit pada penelitian ini adalah komite audit yang beranggotakan 3 orang atau lebih.

Berdasarkan pengertian komite audit yang telah dikemukakan oleh beberapa ahli diatas, maka peneliti menyimpulkan bahwa komite audit adalah suatu komite yang bekerja secara profesional untuk membantu dewan komisaris dalam menjalankan pengawasan pelaporan keuangan.

\section{Kinerja Keuangan}

Kinerja keuangan dalam penelitian ini menggunakan rasio profitabilitas dan Salah satu rasio profitabilitas untuk mengukur kinerja keuangan adalah return on asset (ROA). ROA digunakan untuk mengukur kemampuan perusahaan dalam menghasilkan keuntungan terhadap jumlah aktiva keseluruhan pada suatu perusahaan. Kinerja keuangan adalah suatu analisis yang dilakukan untuk melihat sejauh mana suatu perusahaan telah melaksanakan dengan menggunakan aturan-aturan pelaksanaan keuangan secara baik dan benar(Shofwatun et al., 2021). Profitabilitas menggambarkan keberhasilan operasional perusahaan yang menunjukkan hasil akhir dari sejumlah kebijakan dan keputusan yang diambil oleh manajemen perusahaan( Fauzan et. al.,2020). Semakin baik rasio profitabilitas maka semakin baik nilai lembaga financial tersebut serta menunjukkan bahwa perusahaan mampu dalam mencari keuntungan(Amaliyah \& Alie, 2020). Profitabilitas merupakan rasio untuk menilai kemampuan perusahaan dalam mencari keuntungan dan rasio ini juga memberikan ukuran tingkat efektivitas manajemen suatu perusahaan(Muliana \& Nurbayani, 2019). Rasio profitabilitas mengukur efektivitas manajemen secara keseluruhan yang 
\. • P Jurnal Audit \& Perpajakan

Volume : 1 | Nomor 1 | November 2021 | E-ISSN : 2809-1809. | DOI: 10.47709/jap.v1n1.1165

ditujukkan oleh besar kecilnya tingkat keuntungan yang diperoleh dalam hubungannya dengan penjualan maupun investasi. Semakin baik rasio profitabilitas maka menggambarkan semakin tinggi

kemampuan perolehan laba perusahaan (Fitriyani, 2019). Indikator kinerja keuangan dalam penelitian ini menggunakan return on asset. Menurut(Hantono, 2020), indikator return on asset:

\section{Pengaruh Likuiditas Terhadap Kinerja Keuangan}

$$
\text { Return on Asset }=\frac{\text { Net Income }}{\text { Total Assets }}
$$

Current ratio yang rendah biasanya dianggap menunjukkan terjadinya masalah dalam likuidasi, sebaliknya current ratio yang terlalu tinggi juga kurang bagus, karena menunjukkan banyaknya dana menganggur yang pada akhirnya dapat mengurangi kemampuan laba perusahaan(Hantono, 2016). Likuiditas yang tinggi mengakibatkan semakin tinggi juga kinerja keuangan. Kas merupakan aset lancar yang paling mudah digunakan untuk transaksi apapun termasuk membayar utang. Jika kas perusahaan besar maka perusahaan tersebut memiliki likuiditas yang baik(Mardaningsih et al., 2021). Semakin baik nilai likuiditas, maka diindikasikan kinerja keuangan akan semakin meningkat(Asniwati, 2020). Jika tingkat likuiditas pada suatu perusahaan semakin tinggi maka kinerja keuangan perusahaan akan semakin bagus karena perusahaan dapat dikatakan sanggup untuk membayar kewajibannya secara tepat waktu dan dapat mengoptimalkan penggunaan aset perusahaan(Laksmita et al., 2020). Current Ratio meningkat dikarenakan perusahaan mampu mengoptimalkan modal kerja untuk menjalankan kegiatan operasionalnya yang akan berdampak pada meningkatnya laba artinya setiap kenaikan current ratio maka akan diikuti dengan kenaikan Return on Assets, begitu juga sebaliknya apabila current ratio mengalami penurunan maka akan diikuti dengan penurunan nilai Return on Assets(Yuliani, 2021). Nilai likuiditas yang tinggi menunjukkan bahwa ketersediaan aktiva lancar untuk melunasi kewajiban lancar juga tinggi. Aset lancar meliputi akun seperti kas dan setara kas, piutang, persediaan, dan surat berharga. Namun, rasio lancar yang tinggi tidak serta merta menjamin bahwa perusahaan memiliki cukup kas untuk memenuhi kewajibannya saat ini(Fauzi \& Puspitasari, 2021).

\section{Pengaruh Komite Audit Terhadap Kinerja Keuangan}

Setiap perusahaan yang sudah terdaftar di BEI telah menerapkan standar mengenai jumlah anggota komite audit telah sesuai dengan peraturan yang berlaku sehingga fungsi pengawasan yang dilakukan komite audit dengan baik dapat meningkatkan kualitas laporan keuangan perusahaan.(Shanti, 2020). Banyak-sedikitnya komite audit tidak berdampak pada tinggirendahnya profitabilitas. Walaupun sudah mempunyai sedikitnya 3 (tiga) anggota komite audit sesuai yang diresmikan Kepmen BUMN No: Kep-103/MBU/2001, tetapi tingginya jumlah personel yang dimiliki institusi tersebut tidak dapat mempengaruhi kinerja keuangannya, begitu pula kebalikannya. Ini merupakan imbas adanya keterbatasan tugas serta wewenangnya dalam mendukung dewan komisaris(Fitriyani, 2021). komite audit bertugas membantu dewan komisaris untuk memonitor proses pelaporan keuangan oleh manajemen untuk meningkatkan kredibilitas laporan keuangan, dalam penelitian ini besar kecilnya komite audit tidak mempengaruhi kinerja 
\. • P Jurnal Audit \& Perpajakan

Volume : 1 | Nomor 1 | November 2021 | E-ISSN : 2809-1809. | DOI: 10.47709/jap.v1n1.1165

perusahaan yang di ukur dengan ROA, sebab semua komite audit baik kecil atau banyak mempunyai tugas yang sama yaitu menelaah kebijakan akuntansi yang diterapkan oleh perusahaan, menilai pengendalian internal, menelaah sistem pelaporan eksternal dan kepatuhan terhadap peraturan(Kusumawardhany \& Shanti, 2021). Dengan adanya komite audit dalam suatu perusahaan akan menghasilkan laporan keuangan yang lebih baik dan berkualitas hal ini selaras dengan pencapain tujuan dan tanggung jawab yang harus dipertangungjawabkan oleh komite audit(Dewi \& Fernando, 2020). komite audit hanya memeriksa informasi keuangan yang ada di dalam perusahaan, tetapi tidak berpartisipasi secara langsung dalam menyelesaikan masalah dalam suatu perusahaan. Selain itu, komite audit hanya bertanggung jawab kepada komisaris independen sehingga kurangnya komunikasi dengan pihak lain yang ada di dalam perusahaan(Chandra \& Sormin, 2020). The higher the number of the audit committee of the company, the more it will improve the supervision of the company, especially in the financial statements of the company, so as to reduce the possibility of fraud occurring and preventing the agency conflict and improving the financial performance(Herdjiono \& Sari, 2017).

\section{Pengaruh Leverage Terhadap Kinerja Keuangan}

Semakin tinggi nilai leverage menunjukkan bahwa jumlah utang yang dimiliki oleh perusahaan juga semakin lebih besar daripada modalnya, sehingga biaya yang harus ditanggung untuk memenuhi kewajiban juga akan semakin besar. Akibatnya, profitabilitas perusahaan akan semakin menurun(Kurniawan \& Samhaji, 2020). Perusahaan yang memiliki solvabilitas yang tinggi, maka akan mempunyai resiko kerugian besar, tetapi juga mempunyai kesempatan memperoleh laba yang besar pula dari para penanam modal(Asniwati, 2020). Semakin tinggi tingkat leverage suatu perusahaan maka kinerja keuangan perusahaan akan semakin rendah. Hal ini dikarenakan perusahaan lebih banyak menanggung biaya bunga atau beban tetap sehingga akan menurunkan tingkat profitabilitas suatu perusahaan(Laksmita et al., 2020). Apabila perusahaan tidak mampu mengelola modal karena mempunyai tingkat utang yang tinggi dalam struktur modalnya dan akan menurunkan kinerja keuangan (ROA), karena perusahaan lebih suka menggunakan dana eksternal dari pada dana internal untuk melakukan suatu investasi(Yuliani, 2021). Semakin sedikit jumlah utang mengakibatkan beban utang yang ditanggung juga akan semakin sedikit sehingga dapat memaksimalkan laba yang diperoleh perusahaan(Diana \& Osesoga, 2020).

\section{Metode Penelitian}

Penelitian yang diteliti bertujuan dalam menguji pengaruh antara Likuiditas, Komite Audit, Leverage Terhadap Kinerja Keuangan. Variabel independen yang dipakai adalah Likuiditas, Komite Audit, Leverage. Variabel dependen yang dipakai adalah Kinerja Keuangan Populasi yang digunakan untuk meneliti adalah seluruh perusahaan consumer goods dimana telah terdaftar di Bursa Efek Indonesia yang mempublikasikan laporan keuangan tahunan yang sudah audit dan diumumkan di Bursa Efek Indonesia untuk kurun waktu 2017 - 2020 sebanyak 67. Perusahaan. Sampel dipilih sejumlah 8 perusahaan dengan menggunakan metode purposive sampling. Teknik pengumpulan data menggunakan dokumentasi, adalah sebuah cara mengunduh informasi keuangan tahunan perusahaan consumer goods tahun 2017 - 2020 di Bursa Efek Indonesia dari sebuah situs bernama web.idx.id yang resmi, dilakukan pula kajian pustaka dari jurnal, peraturan, maupun hasil riset berbagai sumber, baik dari buku maupun dari perpustakaan. Menganalisis data 
\. • P Jurnal Audit \& Perpajakan

Volume : 1 | Nomor 1 | November 2021 | E-ISSN : 2809-1809. | DOI: 10.47709/jap.v1n1.1165

dengan memanfaatkan aplikasi SPSS (Statistical Package for the Social Science) versi 26. Metode untuk menganalisis adalah regresi linier berganda. Uji statistik yang terdiri dari uji statistik deskriptif, uji asumsi klasik, uji koefisien determinasi serta uji hipotesis yang terdiri dari uji simultan dan uji parsial.

\section{Hasil}

1. Uji Statistik

a. Statistik Deskriptif

Statistik deskriptif mampu memberikan gambaran atau deskripsi suatu data yang dilihat dari nilai rata-rata (mean), standar deviasi, varian, maksimum, minimum, sum, range, kurtosis, dan kemencengan distribusi. Hasil pengolahan statistik deskriptif terhadap masing-masing variabel dalam penelitian ini adalah sebagai berikut:

Tabel 1. Hasil Uji Statistik Deskriptif

\section{Descriptive Statistics}

\begin{tabular}{lr|r|r|r|r} 
& N & Minimum & Maximum & \multicolumn{1}{c}{ Mean } & \multicolumn{1}{c}{ Std. Deviation } \\
\hline Current_Ratio & 32 & .63 & 5.27 & 2.2106 & 1.31570 \\
\hline DAR & 32 & .15 & .75 & .4038 & .16521 \\
\hline Komite_Audit & 32 & 3.00 & 4.00 & 3.0313 & .17678 \\
\hline ROA & 32 & .00 & .46 & .1379 & .12169 \\
\hline Valid N (listwise) & 32 & & & & \\
\hline
\end{tabular}

\section{Sumber : Data Olahan (2021)}

b. Analisis Regresi Linier Berganda

Analisis regresi linier berganda merupakan suatu metode ataupun teknik untuk melakukan pengujian ada tidaknya pengaruh antara variabel satu dengan variabel lainnya yaitu variabel independen (variabel bebas atau X) terhadap variabel dependen (variabel terikat atau Y) yang dapat dinyatakan dalam bentuk persamaan matematika. Analisis Regresi Linier Berganda dalam penelitian ini adalah sebagai berikut :

\section{Tabel 2 Regresi Linier Berganda}

\begin{tabular}{lc|c|c|c|c}
\multicolumn{7}{c}{ Model } & \multicolumn{5}{c}{ Coefficients $^{\mathbf{a}}$} \\
& $\mathrm{B}$ & Std. Error & $\begin{array}{c}\text { Coefficients } \\
\text { Beta }\end{array}$ & $\mathrm{t}$ & Sig. \\
\hline (Constant) & $\mathbf{- . 8 1 0}$ & .333 & & -2.430 & .022 \\
\hline Current_Ratio & $\mathbf{. 1 0 3}$ & .027 & 1.111 & 3.826 & .001 \\
\hline DAR & $\mathbf{. 8 9 4}$ & .213 & 1.214 & 4.193 & .000 \\
\hline Komite_Audit & $\mathbf{. 1 1 9}$ & .101 & .172 & 1.173 & .251 \\
\hline
\end{tabular}

a. Dependent Variable: ROA

\section{Sumber : Data Olahan (2021)}

Model persamaan regresi linear berganda pada penelitian ini adalah sebagai berikut: ROA $=-0.810+0.103$ Current_Ratio +0.894 DAR +0.119 Komite_Audit 


\section{- 1 - P Jurnal Audit \& Perpajakan}

Volume : 1 | Nomor 1 | November 2021 | E-ISSN : 2809-1809. | DOI: 10.47709/jap.v1n1.1165

c. Uji Asumsi Klasik

Uji Asumsi Klasik Salah satu uji normalitas yang digunakan dalam penelitian ini adalah uji statistik Kolmogorov-Sminov (K-S). Hasil uji statistik Kolmogorov-Sminov (K-S) adalah sebagai berikut:

Tabel 3 Uji Statistik Kolmogorov-Sminov

One-Sample Kolmogorov-Smirnov Test

\begin{tabular}{llr} 
& & Unstandardized Residual \\
\hline $\mathrm{N}$ & & 32 \\
\hline \multirow{2}{*}{ Normal Parameters } & Mean & .0000000 \\
\cline { 2 - 3 } & Std. Deviation & .09358680 \\
\hline \multirow{2}{*}{ Most Extreme Differences } & Absolute & .117 \\
\cline { 2 - 3 } & Positive & .117 \\
\cline { 2 - 3 } & Negative & -.080 \\
\hline Test Statistic & & .117 \\
\hline Asymp. Sig. (2-tailed) & & $\mathbf{. 2 0 0}^{\mathbf{c , d}}$ \\
\hline
\end{tabular}

a. Test distribution is Normal.

b. Calculated from data.

c. Lilliefors Significance Correction.

d. This is a lower bound of the true significance.

\section{Sumber : Data Olahan (2021)}

Dari tabel di atas terlihat bahwa nilai sig nya lebih besar dari 0.05 sementara syarat nilai signifikansinya harus lebih besar dari 0,05 maka dapat dikatakan bahwa data tersebut berdistribusi normal.

d. Uji Multikolinearitas

Pada uji multikolinearitas dapat dilihat dimana jika nilai Variance Inflation Factor (VIF) tidak lebih dari 10 dan nilai tolerance tidak kurang dari 0,1, maka model tersebut dapat dikatakan terbebas dari multikolinearitas, sedangkan jika nilai VIF lebih besar dari 10 maka diindikasikan model tersebut memiliki gejala multikolinearitas.

\section{Tabel 4 Uji Multikolinearitas}

\section{Coefficients $^{\mathbf{a}}$}

\begin{tabular}{llc|c} 
& \multicolumn{2}{c}{ Model } & Collinearity Statistics \\
& Tolerance & VIF \\
\hline 1 & Current_Ratio & $\mathbf{. 2 5 0}$ & $\mathbf{3 . 9 9 2}$ \\
\cline { 2 - 4 } & DAR & $\mathbf{. 2 5 2}$ & $\mathbf{3 . 9 6 9}$ \\
\cline { 2 - 4 } & Komite_Audit & $\mathbf{. 9 7 8}$ & $\mathbf{1 . 0 2 2}$ \\
\hline
\end{tabular}

a. Dependent Variable: ROA

Sumber : Data Olahan (2021) 


\section{- 1 - P Jurnal Audit \& Perpajakan}

Volume : 1 | Nomor 1 | November 2021 | E-ISSN : 2809-1809. | DOI: 10.47709/jap.v1n1.1165

Berdasarkan tabel di atas diketahui bahwa semua variabel independen mempunyai angka VIF di bawah angka 10 dan nilai tolerance lebih besar dari 0,10. Berdasarkan hasil pengujian tersebut, maka dapat disimpulkan bahwa tidak terjadi masalah multikolinearitas.

e. Uji Autokorelasi

Uji Autokorelasi dilakukan untuk mengetahui apakah dalam model regresi linear terdapat korelasi antara kesalahan pengganggu pada periode $t$ dan dengan kesalahan pengganggu pada periode t-1 (sebelumnya) dan pada penelitian ini menggunakan uji run test untuk melakukan uji autokorelasi seperti pada tabel di bawah ini :

Tabel 5 Uji Autokorelasi

\section{Runs Test}

Unstandardized Residual

\begin{tabular}{lr}
\hline Test Value $^{\mathrm{a}}$ & -.02614 \\
\hline Cases $<$ Test Value & 15 \\
\hline Cases $>=$ Test Value & 16 \\
\hline Total Cases & 31 \\
\hline Number of Runs & 12 \\
\hline Z & -1.457 \\
\hline Asymp. Sig. (2-tailed) & $\mathbf{. 1 4 5}$ \\
\hline
\end{tabular}

a. Median

Sumber : Data Olahan (2021)

Berdasarkan output tersebut diperoleh nilai probabilitas lebih besar daripada 0,05, Dengan demikian maka tidak terjadi autokorelasi.

f. Uji Heteroskedastisitas

Uji heteroskedastisitas digunakan untuk menguji apakah dalam model regresi terjadi ketidaksamaan varians, dari residual satu pengamatan ke pengamatan yang lain. Model regresi yang baik adalah yang tidak terjadi heteroskedastisitas pada model persamaan regresi. Uji statistik yang digunakan adalah uji grafik Scatterplot. Uji Scatterplot yaitu melihat grafik plot antara nilai prediksi variabel terikat (dependen) yaitu ZPRED dengan residualnya SRESID yang dilakukan dengan melihat ada atau tidaknya pola tertentu pada grafik Scatterplot antara SRESID dan ZPRED dimana sumbu Y adalah Y yang telah diprediksi, dan sumbu $\mathrm{X}$ adalah residual (Y prediksi - Y sesungguhnya). 


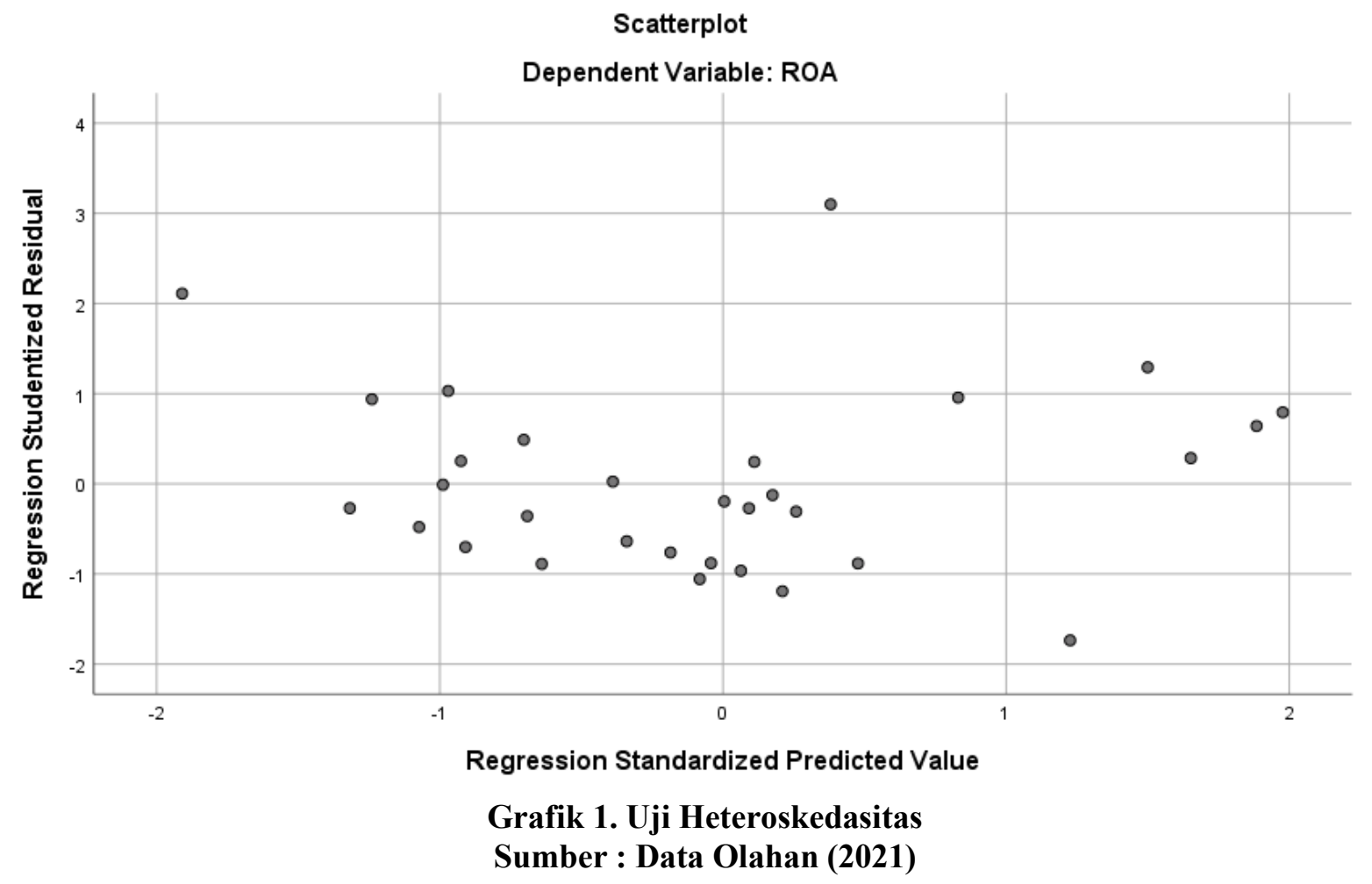

Berdasarkan grafik scatterplot menunjukkan bahwa titik-titik tersebar secara acak (tidak berpola) baik di atas maupun di bawah angka 0 (nol) pada sumbu $\mathrm{Y}$ sehingga dapat disimpulkan bahwa model persamaan dalam penelitian ini telah memenuhi asumsi homoskedastisitas atau tidak terjadi heteroskedastisitas.

g. Uji Koefisien Determinasi

Uji koefisien determinasi berganda (adjusted $\mathrm{R}^{2}$ ) digunakan untuk mengetahui seberapa besar variabel independen dapat menjelaskan variabel dependen dalam penelitian ini, sehingga dalam penelitian ini uji koefisien determinasi berganda (adjusted $\mathrm{R}^{2}$ ) akan memberikan seberapa besar likuiditas, leverage dan komite audit dapat menjelaskan kinerja keuangan.

\section{Tabel 6 Uji Koefisien Determinasi}

\begin{tabular}{ll|r|r|r|r} 
& & \multicolumn{5}{c}{$\begin{array}{c}\text { Model Summary } \\
\text { Adjusted R } \\
\text { Model }\end{array}$} & R & R Square & \multicolumn{1}{c}{$\begin{array}{c}\text { Std. Error of the } \\
\text { Square }\end{array}$} & Estimate & Durbin-Watson \\
\hline 1 & $.731^{\mathrm{a}}$ & $\mathbf{. 5 3 5}$ & .483 & .16397 & .752 \\
\hline
\end{tabular}

a. Predictors: (Constant), lag_Komite_Audit, lag_DAR, lag_Current_Ratio

b. Dependent Variable: lag_ROA

Sumber : Data Olahan (2021)

Nilai Adjusted $R$ Square pada tabel di atas sebesar 0,535 artinya bahwa kontribusi variabel likuiditas, leverage dan komite audit dalam menjelaskan variable kinerja keuangan yang 
diproksi dengan return on assets ialah sebesar 53.5\% dan dan sisanya 46,5\% dijelaskan oleh variabel lain diluar variabel yang diuji.

\section{Uji Hipotesis}

a. Uji Secara Simultan (Uji F)

Uji f digunakan untuk menguji tingkat pengaruh variabel independen terhadap variabel dependen secara bersama-sama. Dalam uji F kesimpulan yang diambil adalah dengan melihat signifikansi 5\% atau 0,05. Berdasarkan tabel 6 dapat diketahui bahwa nilai signifikansi $(\alpha) 0.002<0.05$ dengan nilai $F_{\text {hitung }} 6.447<F_{\text {tabel }} 2.90$ yang berarti bahwa variabel independen mempunyai pengaruh signifikan secara bersama-sama (simultan) terhadap variabel independen.

\section{Tabel 7 Uji F \\ ANOVA ${ }^{a}$}

\begin{tabular}{lc|c|c|c|c}
\multicolumn{1}{c}{ Model } & Sum of Squares & Df & Mean Square & F & Sig. \\
\hline Regression & .188 & 3 & .063 & $\mathbf{6 . 4 4 7}$ & $\mathbf{. 0 0 2}^{\mathbf{b}}$ \\
\cline { 2 - 7 } 1 & .272 & 28 & .010 & & \\
\cline { 2 - 6 } Residual & .459 & 31 & & & \\
\hline
\end{tabular}

a. Dependent Variable: ROA

b. Predictors: (Constant), Komite_Audit, DAR, Current_Ratio

Sumber : Data Olahan (2021)

b. Uji Secara Parsial (Uji t)

Uji t digunakan untuk mengetahui pengaruh variabel bebas independen terhadap variabel dependen dan uji t digunakan untuk melihat pengaruh secara satu per satu atau secara parsial. Hasil pengujian parsial dapat dilihat pada tabel berikut ini

\section{Tabel 8 Uji t}

\section{Coefficients $^{\mathbf{a}}$}

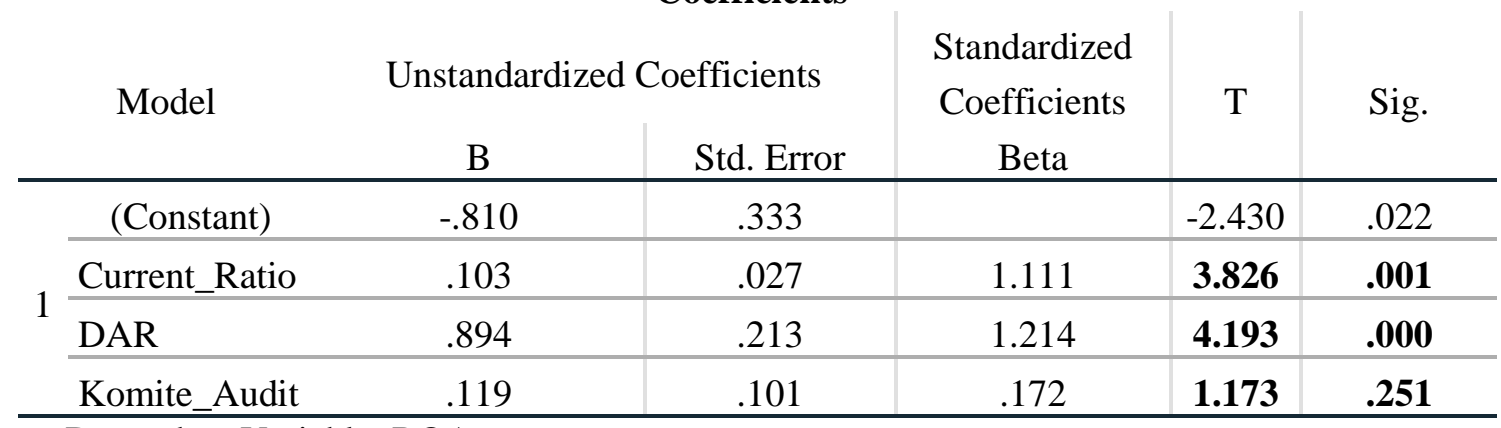

a. Dependent Variable: ROA

Sumber : Data Olahan (2021)

Berdasarkan output di atas coefficients diperoleh hasil sebagai berikut :

a. Pengaruh parsial antara current ratio dengan return on assets, dimana thitung sebesar 3.826 dan nilai $t_{\text {tabel }}$ sebesar 2.051 yang diperoleh dari formula $(\alpha / 2 ; \mathrm{n}-\mathrm{k}-1),(\alpha / 2 ; 32-4-1)$ $=27$ maka $t_{\text {tabel }}=2.051$. Sehingga nilai $t_{\text {hitung }}>t_{\text {tabel }}$ dengan nilai signifikansi 0.001 lebih 
\. • P Jurnal Audit \& Perpajakan

Volume : 1 | Nomor 1 | November 2021 | E-ISSN : 2809-1809. | DOI: 10.47709/jap.v1n1.1165

kecil dari 0.05 , dengan demikian terdapat pengaruh antara variabel current ratio $\left(\mathrm{X}_{1}\right)$ terhadap return on assets $(\mathrm{Y})$.

b. Pengaruh parsial antara debt to asset ratio dengan return on assets, dimana nilai thitung sebesar 4.193 dan nilai tabel sebesar 2.051 yang diperoleh dari formula $(\alpha / 2 ; \mathrm{n}-\mathrm{k}-1),(\alpha / 2 ; 32-$ $4-1)=27$ maka $t_{\text {tabel }}=2.051$ sehingga nilai $t_{\text {hitung }}>t_{\text {tabel }} 2.060$ dengan nilai signifikansi 0.000 lebih kecil dari 0.05 , dengan demikian terdapat pengaruh antara variabel DAR $\left(\mathrm{X}_{2}\right)$ terhadap return on assets $(\mathrm{Y})$.

c. Pengaruh parsial antara komite audit dengan return on assets, dimana thitung sebesar 1.173 dan nilai tabel sebesar 2.051 yang diperoleh dari formula $(\alpha / 2 ; \mathrm{n}-\mathrm{k}-1),(\alpha / 2 ; 32-4-1)$ $=27$ maka $t_{\text {tabel }}=2.051$ sehingga nilai $t_{\text {hitung }}<t_{\text {tabel }} 2.060$ dengan nilai signifikansi 0.251 lebih besar dari 0.05 , dengan demikian terdapat pengaruh antara variabel komite audit $\left(\mathrm{X}_{3}\right)$ terhadap return on assets $(\mathrm{Y})$.

\section{Pembahasan}

\section{Pengaruh Current Ratio Terhadap Return on Assets}

Hasil penelitian menunjukkan terdapat pengaruh antara variabel current ratio $\left(\mathrm{X}_{1}\right)$ terhadap return on assets (Y) pada consumer goods yang terdaftar di Bursa Efek Indonesia Periode 2017 - 2020. Hasil penelitian ini sejalan dengan penelitian yang dilakukan oleh (Hantono, 2016), (Mardaningsih et al., 2021), (Asniwati, 2020), (Laksmita et al., 2020), (Yuliani, 2021), (Fauzi \& Puspitasari, 2021). Berdasarkan hasil penelitian ini dapat disimpulkan bahwa apabila nilai rasio lancar besar maka bisa dikatakan bagus dikarenakan memiliki nilai likuiditas yang besar dengan demikian perusahaan mampu untuk membayar hutang jangka pendeknya sehingga semakin besar rasio lancar, maka menunjukkan semakin besar kemampuan perusahaan untuk memenuhi kewajiban jangka pendeknya. Hal ini menunjukkan perusahaan melakukan penempatan dana yang besar pada sisi aktiva lancar sehingga penempatan dana yang terlalu besar pada sisi aktiva memiliki dua efek yang sangat berlainan dan di satu sisi, likuiditas perusahaan semakin baik. Namun di sisi lain, perusahaan kehilangan kesempatan untuk mendapatkan tambahan laba, karena dana yang seharusnya digunakan untuk investasi yang menguntungkan perusahaan, dicadangkan untuk memenuhi likuiditas. Namun hasil penelitian ini tidak sejalan dengan penelitian yang dilakukan oleh (Barus \& Leliani, 2013), (Margaretha \& Khairunisa, 2016), (Madushanka \& Jathurika, 2018), (Melani et al., 2019), (Tumanggor, 2020), dan (Hantono, 2020) dimana hasil ini bisa disimpulkan bahwa apabila current ratio mengalami kenaikan maka akan menurunkan return on assets, sebaliknya apabila current ratio mengalami penurunan maka akan menaikkan nilai return on assets.

\section{Pengaruh Debt to Asset Ratio dengan Return on Assets}

Hasil penelitian menunjukkan bahwa secara parsial terdapat pengaruh debt to assets ratio dengan return on assets pada consumer goods yang terdaftar di Bursa Efek Indonesia Periode 2017 - 2020. Hasil penelitian ini sejalan dengan penelitian yang dilakukan oleh (Kurniawan \& Samhaji, 2020), (Asniwati, 2020), (Laksmita et al., 2020), (Yuliani, 2021), (Diana \& Osesoga, 2020). Berdasarkan hasil penelitian ini bisa disimpulkan bahwa semakin besar rasio yang dihasilkan oleh leverage yang diproksi debt to assets ratio maka semakin besar pula penggunaan hutang yang digunakan untuk membiayai investasi pada aktiva yang mengakibatkan leverage yang diperoleh perusahaan semakin besar. Namun hasil penelitian ini tidak sejalan dengan penelitian yang dilakukan oleh 
\. • P Jurnal Audit \& Perpajakan

Volume : 1 | Nomor 1 | November 2021 | E-ISSN : 2809-1809. | DOI: 10.47709/jap.v1n1.1165

(Alghusin, 2015),(Kartikasari \& Merianti, 2016),(Rusmawati, 2016). Hal tidak sejalan ini dikarenakan semakin rendah risiko keuangannya karena perusahaan sedikit melakukan pendanaan aktiva dari utang sehingga analisis yang dapat diberikan adalah bahwa debt to assets ratio yang rendah akan meningkatkan profitabilitas perusahaan karena menurunnya biaya bunga dan risiko gagal bayar, karena apabila debt to assets ratio yang rendah akan membantu kemampuan pendanaan operasional perusahaan tersebut dalam rangka meningkatkan profitabilitas.

\section{Pengaruh Komite Audit dengan Return on Assets}

Hasil penelitian menunjukkan bahwa secara parsial tidak terdapat pengaruh komite audit dengan return on assets pada consumer goods yang terdaftar di Bursa Efek Indonesia Periode 2017 - 2020. Hasil penelitian ini sejalan dengan penelitian yang dilakukan oleh (Shanti, 2020), (Fitriyani, 2021), (Kusumawardhany \& Shanti, 2021), (Dewi \& Fernando, 2020), (Chandra \& Sormin, 2020). Berdasarkan hasil penelitian ini dapat disimpukan bahwa jumlah jumlah komite audit tidak memiliki pengaruh yang signifikan terhadap kinerja keuangan perusahaan dan juga keberadaan komite audit dirasakan belum efektif karena disebabkan oleh pemahaman akan fungsi, tugas, dan tanggung jawab komite audit yang masih sangat bervariasi. Beragamnya pemahaman ini memicu ketidakefektifan komite audit dalam menjalankan fungsinya, yang pada akhirnya dapat menyebabkan tidak terwujudnya kualitas penerapan prinsip-prinsip corporate governance secara optimal, sehingga berdampak menurunkan kinerja perusahaan. Hasil penelitian ini tidak sejalan dengan penelitian yang dilakukan oleh (Wijayanti \& Mutmainah, 2012), (Xie et al, 2012), (Yasser, et al, 2011), Berdasarkan uraian tersebut, Hal ini menunjukkan bahwa jumlah komite audit tidak menjamin keefektifan kinerja komite audit dalam melakukan pengawasan terhadap kinerja keuangan perusahaan.

\section{Kesimpulan}

Berdasarkan hasil penelitian, dapat disimpulkan bahwa :

1. Secara parsial, hasil penelitian menunjukkan bahwa current ratio dan debt to asset ratio berpengaruh terhadap return on assets pada perusahaan consumer goods yang terdaftar di Bursa Efek Indonesia Periode 2017 - 2020, sementara variabel komite audit tidak berpengaruh terhadap return on assets pada perusahaan consumer goods yang terdaftar di Bursa Efek Indonesia Periode 2017 - 2020.

2. Variabel likuditas, leverage dan komite audit berpengaruh terhadap return on assets pada perusahaan consumer goods yang terdaftar di Bursa Efek Indonesia Periode 2017 - 2020.

3. Nilai Adjusted $R$ Square pada penelitian ini sebesar 0,535 artinya bahwa kontribusi variabel likuiditas, leverage dan komite audit dalam menjelaskan variable kinerja keuangan yang diproksi dengan return on assets ialah sebesar 53.5\% dan dan sisanya 46,5\% dijelaskan oleh variabel lain diluar variabel yang diuji.

\section{Referensi}

Alghusin, N. A. S. (2015). Do Financial Leverage, Growth and Size Affect Profitability of Jordanian Industrial Firms Listed? International Journal of Academic Research in Business and Social Sciences, 5(4), 385-398. https://doi.org/10.6007/ijarbss/v5-i4/1580

Agbaje, O. B. A., Wakil, S. M., \& Osowole, A. A. (2014). Synthesis, Spectroscopic Characterization and Antimicrobial Activities of Some Mixed Drug Metal (II) Complexes of 
\. • P Jurnal Audit \& Perpajakan

Volume : 1 | Nomor 1 | November 2021 | E-ISSN : 2809-1809. | DOI: 10.47709/jap.v1n1.1165

Sulfamethoxazole and Paracetamol. Journal of Accounting and Auditing: Research \& Practice, 2014(2014), 1-12. https://doi.org/10.5171/2014

Asniwati. (2020). Pengaruh Rasio Likuiditas, Solvabilitas, dan Profitabilitas Terhadap Kinerja Keuangan Pada PT. Midi Utama Indonesia Tbk Yang Terdaftar Di Bursa Efek Indonesia. Economix, 8(1), 246-257.

Amaliyah, A. R., \& Alie, R. M. M. (2020). Analisa Kinerja Keuangan pada Koperasi Uber Kepanjen melalui Rasio Likuiditas, Solvabilitas dan Profitabilitas. Inventory: Jurnal Akuntansi, 4(1), 33-40.

Barus, A. C., \& Leliani. (2013). Analisis Faktor-Faktor yang Mempengaruhi Profitabilitas pada Perusahaan Manufaktur yang Terdaftar di Bursa Efek Indonesia. JWEM (Jurnal Wira Ekonomi Mikroskil), 3(2), 111-121.

Chandra, Kristi Oktaviani.\& Partogi Sormin. (2020). Pengaruh Good Corporate Governance Terhadap Kinerja Keuangan (Studi Empiris Perusahaan Publik Industri Barang Komsumsi yang Terdaftar di BEI). Jurnal Penelitian Akuntansi, 1(2), 136-144.

Dj,Yunni Rusmawati. (2016). Pengaruh Ukuran Perusahaan, Struktur Hutang, Dan Umur Perusahaan Terhadap Profitabilitas Pada Perusahaan Food \& Beverages Di Bursa Efek Indonesia Tahun 2012-2014. Jurnal Penelitian Ekonomi Dan Akuntansi, I(2), 111-126.

Dewi, A. S., \& Fernando, R. T. (2020). Dewan Komisaris Independen dan Komite Audit sebagai Faktor yang Menentukan Kinerja Keuangan Perusahaan Manufaktur yang Terdaftar di Bursa Efek Indonesia Periode 2013-2017. Jurnal Pundi, 4(1), 1-12. https://doi.org/10.31575/jp.v4i1.220

Fitriyani, H. A. (2019). Pengaruh Net Profit Margin (NPM) dan Biaya Operasional Pendapatan Operasional (BOPO) Terhadap Return on Assets (ROA) (Pada Perusahaan Transportasi Yang Terdaftar Di Bursa Efek Indonesia Tahun 2013-2015). Jurnal Bisnis Dan Akuntansi Unsurya, 4(2), 94-106.

Fauzi, A. F., \& Puspitasari, E. (2021). Pengaruh Struktur Modal, Ukuran Perusahaan, Likuiditas Dan Pertumbuhan Aset Terhadap Kinerja Keuangan Perusahaan Yang Terdaftar Di Jakarta Islamic Index (JII) Periode 2018-2020. Edunomika, 05(02), 1130-1141.

Fitriyani, Y. (2021). Pengaruh Dewan Komisaris, Dewan Direksi Dan Komite Audit Terhadap Profitabilitas Perbankan Di Bei Tahun 2017-2019. Jurnal Ilmiah MEA (Manajemen, Ekonomi, Dan Akuntansi), 5(2), 849-867.

Haqiqi, Fauzan, Darmawan Fadli, K. (2020). Analisis Pengaruh Likuiditas Dan Pemberian Kredit Terhadap Tingkat Profitabilitas Pada Bank BPR Mega Mas Lestari Tahun 2016-2018 Kabupaten Karimun. JURNAL CAFETARIA, 1(1), 73-83.

Herdjiono, I., \& Sari, I. M. (2017). The Effect of Corporate Governance on The Performance of a company. Journal of Management and Business Administration. Central Europe, 25(1), 3352. https://doi.org/10.7206/jmba.ce.2450-7814.188

Hantono (2020). Corporate Finance. Makasar. Yayasan Barcode

Hantono (2017). Konsep Analisa Laporan Keuangan dengan Pendekatan Rasio dan SPSS. Yogyakarta : Deepublish.

Hantono. (2020). Pengaruh Likuiditas, Leverage Dan Modal Kerja Terhadap Profitabilitas Pada Perusahaan Transportasi Yang Terdaftar Di Bursa Efek Indonesia Pada Periode 2014-2018. Journal of Accounting \& Management Innovation, 4(1), 37-46.

Irma Melani, Suroso, S., \& Nurul Musqori. (2019). The Effect of Capital Adequacy and Liquidity 


\section{- 1 - P Jurnal Audit \& Perpajakan}

Volume : 1 | Nomor 1 | November 2021 | E-ISSN : 2809-1809. | DOI: 10.47709/jap.v1n1.1165

on Profitability in Food and Beverage Sub Sector Manufacturing Companies Listed on the Indonesia Stock Exchange (ISE) Period 2015-2018. Ilomata International Journal of Management, 1(1), 1-7. https://doi.org/10.52728/ijjm.v1i1.27

Otoritas Jasa Keuangan. 2015. Peraturan Otoritas Jasa Keuangan No. 55/POJK.04/2015 Tentang Pembentukan Pedoman Pelaksanaan Kerja Komite Audit. Jakarta.

Kartikasari, D., \& Merianti, M. (2016). The effect of leverage and firm size to profitability of public manufacturing companies in Indonesia. International Journal of Economics and Financial Issues, 6(2), 409-413

Kurniawan, D., \& Samhaji. (2020). Pengaruh Leverage, Likuiditas, Dan Ukuran Perusahaan Terhadap Kinerja Keuangan Emited Perbankan Yang Terdaftar Di Bursa Efek Indonesia. Jurnal Manajemen, 16(2), 62-75.

Kusumawardhany, S. S., \& Shanti, Y. K. (2021). Pengaruh Pengaruh Komite Audit, Dewan Komisaris Dan Dewan Direksi Terhadap Kinerja Keuangan Perusahaan. Journal of Information System, Applied, Management, Accounting and Research, 5(2), 400-412. https://doi.org/10.52362/jisamar.v5i2.383

Laksmita, K. A., Sumadi, N. K., \& Karyada, I. P. F. (2020). Pengaruh Likuiditas dan Leverage Terhadap Kinerja Keuangan Perusahaan Dengan Manajemen Aset Sebagai Variabel Pemoderasi (Studi Empiris Sektor Perdagangan Dan Jasa Non Keuangan Yang Terdaftar Di Bursa Efek Indonesia Periode 2016-2018). Hita Akuntansi Dan Keuangan, 1(2), 1-28. https://ejournal.unhi.ac.id/index.php/HAK/article/view/972.

Margaretha, F., \& Khairunisa. (2016). Pengaruh Struktur Modal dan Likuiditas terhadap Profitabilitas pada Usaha Kecil dan Menengah di Indonesia. Jurnal Manajemen Bisnis (JAB), 11(2), 129-140.

Madushanka, K. H. I., \& Jathurika, M. (2018). "The Impact of Liquidity Ratios on Profitability (With special reference to Listed Manufacturing Companies in Sri The Impact of Liquidity Ratios on Profitability (With special reference to Listed Manufacturing Companies in Sri Lanka). International Research Journal of Advanced Engineering and Science, 3(4), 157161.

Muliana \& Nurbayani. (2019). Analisis Profitabilitas Untuk Mengukur Kinerja Keuangan Manajemen Hotel Syariah "Al Badar" Di Kota Makassar. SEIKO : Journal of Management \& Business, 3(1), 1. https://doi.org/10.37531/sejaman.v3i1.466.

Mardaningsih, D., Nurlaela, S., \& Wijayanti, A. (2021). Pengaruh Leverage, Likuiditas, Firm Size dan Sales Growth Terhadap Kinerja Keuangan Pada Perusahaan LQ45. Inovasi, 17(1), 4653. http://journal.feb.unmul.ac.id/index.php/INOVASI/article/view/9133

Nurcahyani, D. R., \& Situngkir, T. L. (2021). Dampak Rasio Likuiditas , Solvabilitas dan Profitabilitas Terhadap Potensi Kebangkrutan Perusahaan. Jurnal Manajemen, 13(2), 324331.

Purba, I. A. P. L., \& Candradewi, M. R. (2019). Pengaruh Leverage, Likuiditas, Profitabilitas Dan Ukuran Perusahaan Terhadap Pengungkapan Corporate Social Responsibility. E-Jurnal Manajemen Universitas Udayana, $\quad 8(9), \quad 5372$. https://doi.org/10.24843/ejmunud.2019.v08.i09.p02.

Prabowo, R., \& Sutanto, A. (2019). Analisis Pengaruh Struktur Modal, dan Likuiditas terhadap Profitabilitas pada Perusahaan Sektor Otomotif di indonesia. Jurnal Samudra Ekonomi Dan Bisnis, 10(1), 1-11. https://doi.org/10.33059/jseb.v10i1.1120. 
\. • P Jurnal Audit \& Perpajakan

Volume : 1 | Nomor 1 | November 2021 | E-ISSN : 2809-1809. | DOI: 10.47709/jap.v1n1.1165

Rotua Margaretta, Romahot Rezeky br. Pasaribu, A. L. (2019). Analisis Perbandingan Likuiditas, Solvabilitas dan Profitabilitas Di Ace Hardware Indonesia, Tbk. Pada Tahun 2016 - 2018. Jurnal Ilmiah Methonomi, 5(1), 49-56.

Riswanto, A. (2021). Pengaruh Leverage Dan Profitabilitas Terhadap Nilai Perusahaan (Studi Empiris 16 Perusahaan Sektor Konsumsi Yang Terdaftar Di Bursa Efek Indonesia). Jurnal Aktiva : Riset Akuntansi Dan Keuangan, 2(3), 7-20.

Shabrina, N. (2019). Analisis Rasio Profitabilitas Dan Rasio Likuiditas Untuk Menilai Kinerja Keuangan Pada Pt. Astra Internasional,Tbk. JIMF (Jurnal Ilmiah Manajemen Forkamma), 2(3), 62-75. https://doi.org/10.32493/frkm.v2i3.3398.

Sofiantin, D. A. (2020). Pengaruh Profitabilitas, Leverage, Likuiditas, Ukuran Perusahaan, Kebijakan Deviden Terhadap Nilai Perusahaan (Studi Empiris pada Perusahaan Manufaktur subsektor Industri dan Kimia yang terdaftar di BEI periode 2014-2018). Prisma (Platform Riset Mahasiswa Akuntansi), 1(1), 47-57. https://ojs.stiesa.ac.id/index.php/prisma.

Shofwatun, H., Kosasih, K., \& Megawati, L. (2021). Analisis Kinerja Keuangan Berdasarkan Rasio Likuiditas Danrasio Profitabilitas Pada Pt Pos Indonesia (Persero). KRISNA: Kumpulan Riset Akuntansi, 13(1), 59-74. https://doi.org/10.22225/kr.13.1.2021.59-74

Setiawati, L., Juhendi, N., \& Yusuf, B. P. (2020). Pengaruh Profitabilitas, Leverage, dan Firm Size Terhadap Peringkat Obligasi Bank Konvensional Periode 2015-2019. Jurnal Manajemen Bisnis Dan Publik, 1(1), 78-92. https://doi.org/10.22236/jmbp.v1i1.5686.

Tumanggor, M. (2020). The Influence of Current Ratio, Quick Ratio and Net Profit Margin on Return on Assets at PT. Hero Supermarket Tbk. PINISI Discretion Review, 1(1), 137. https://doi.org/10.26858/pdr.v1i1.13388

Quan, V. C., \& Ardiansyah. (2020). Pengaruh Financial Leverage , Firm Size Dan Free Cash Flow Terhadap Financial Performance. Multiparadigma Akuntansi Tarumanagara, 2(April), 920929.

Wijayanti, S., \& Mutmainah, S. (2012). Pengaruh Penerapan Corporate Governance Perbankan Yang Terdaftar Di Bursa Efek Indonesia. Diponegoro Journal of Accounting, 1(2), 1-15

Xie, B., W.N. Davidson, dan P.J. DaDalt. 2003. "Earnings Management and Corporate Governance: The Role of Board and The Audit Committee". Journal of Corporate Finance, $9,295-316$.

Yasser, Q.R. et al. 2011. Corporate Governance and Firm Performance in Pakistan: The Case of Karachi Stock Exchange (KSE)-30. Journal of Economics and International Finance. 3(8).482-491.

Yuliani, E. (2021). Pengaruh Struktur Modal , Likuiditas dan Pertumbuhan Penjualan Terhadap Kinerja Keuangan Pada Perusahaan Go Publik yang. Ilmu Manajemen, 10(2), 111-122. https://doi.org/10.32502/jimn.v10i2.3108 